and Mrs P Hopgood for cholesterol estimations; our clerical and computing staff; and our nurses, especially Miss $M$ Alderton, Miss A Gregg, and Miss $\mathrm{K}$ Oldale. The study was supported by the Department of Health and Social Security, who have been most helpful throughout. Neo-Naclex-K and reserpine tablets were provided by Glaxo Ltd.

The following companies and occupational physicians participated: British Airways (Drs D M Bruton, I M Dawson, C C G Rawll); British Steel Corporation (Drs J A E Richards, G B Downs, A Sinclair, C F Ross, the late C R Thomas, J B Watkins); CadburySchweppes Ltd (Dr C White); Central Middlesex Industrial Health Service (the late Dr G E Ffrench); Guest Keen Nettlefold Ltd (Drs P L Pelmear, J A Rigby, L E Tyler); Guinness Ltd (Dr B M Watney); Ilford Ltd (Drs V O Stewart, D Coull); Kodak Ltd (Drs M Falconer, G Hughes, K W Harbord, T Kelly); May and Baker Ltd (Dr J Cuthbert); Philips Industries (Dr D J Terry); Royal Ordnance Factory (the late Dr Tyrer, Dr C Edwards); Shell Chemicals UK Ltd (Drs B George, S H M Logan); Slough Industrial Health Service (Dr C M S Coppin); Tate and Lyle Refineries Ltd (Dr G L MacLeod).

\section{References}

${ }^{1}$ Joint Working Party of the Royal College of Physicians of London and the British Cardiac Society. Prevention of coronary heart disease. f R Coll Physicians Lond 1976;10:213-75.

2 Rose G. A proposed trial of heart disease prevention in industry. Trans Soc Occup Med 1970;20:109-11.

3 WHO European Collaborative Group. An international controlled trial in the multifactorial prevention of coronary heart disease. Int $\mathcal{f}$ Epidemiol $1974 ; 3: 219-24$.

4 Walker SH, Duncan DB. Estimation of the probability of an event as a function of several independent variables. Biometrika 1967;54:167-79.

5 Committee of Principal Investigators. A co-operative trial in the primary prevention of ischaemic heart disease using clofibrate. $\mathrm{Br}$ Heart $\mathcal{F}$ $1978 ; 40: 1069-118$.

${ }^{6}$ Puska P. North Karelia Project, a programme for community control of cardiovascular diseases. Publications of the University of Kuopio. Community Health 1974; Series A:1.

${ }^{7}$ Farquhar JW, Maccoby N, Wood PD, et al. Community education for cardiovascular health. Lancet $1977 ; \mathrm{i}: 1192-5$.

\title{
Vitamin D supplements in pregnant Asian women: effects on calcium status and fetal growth
}

\author{
O G BROOKE, I R F BROWN, C D M BONE, N D CARTER, H J W CLEEVE, \\ J D MAXWELL, V P ROBINSON, S M WINDER
}

\section{Summary and conclusions}

In a double-blind trial of vitamin $D$ supplements in pregnant Asian women calciferol (ergocalciferol, 1000 IU/day) was administered to 59 women and placebo to 67 controls during the last trimester. The two groups had similar distributions of maternal age, height, parity, number of vegetarians, countries of origin, and sex and gestation of the infants.

At entry to the trial maternal serum 25-hydroxy vitamin $D$ (25-OHD) concentrations were low in both treatment and control groups and significantly lower in vegetarians than non-vegetarians. Mothers in the treatment group gained weight faster in the last trimester than those in the control group, and at term they and their infants all had adequate plasma 25-OHD concentrations. Mothers and infants in the control group, however, had low plasma concentrations of 25-OHD

St George's Hospital, London SW17 ORE

Department of Child Health

O G BROOKE, MD, MRCP, senior lecturer

N D CARTER, PHD, senior lecturer

Department of Chemical Pathology

I R F BROWN, PHD, MRCPATH, lecturer

H J W CLEEVE, FRCPATH, senior lecturer

Department of Obstetrics and Gynaecology

V P ROBINSON, MRCOG, senior registrar

C D M BONE, MRCOG, senior registrar

Department of Medicine

J D MAXWELL, MD, FRCP, senior lecturer

Pharmacy

S M WINDER, BPHARM, MPS, staff pharmacist and calcium and raised plasma alkaline phosphatase (bone isoenzyme) activity. Five of these infants developed symptomatic hypocalcaemia. Almost twice as many infants in the control group were small for gestational age $(29 \% v 15 \%)$, but there were no significant differences between the two groups of infants in anthropometric measurements. Infants in the control group, however, had larger fontanelles, suggesting impaired ossification of the skull.

Because of the benefits to mothers and infants in the treatment group and the absence of side effects, vitamin D supplements should be given to all pregnant Asian women in the United Kingdom.

\section{Introduction}

Despite improved living standards there is continuing clinical and biochemical evidence of vitamin D deficiency in Asian immigrants, both among children and adults. ${ }^{1}$ This problem is not confined to Scotland and the north of England, where winter sunlight hours are short, and Turton et al recently showed that vitamin D deficiency occurred in pregnant Asian women in the south London district of Tooting, which contains a relatively affluent Asian community. ${ }^{2}$

Osteomalacia is a well-recognised complication of pregnancy in Asians living in the United Kingdom. ${ }^{3}$ Asian women appear to be particularly at risk of vitamin $\mathrm{D}$ deficiency during pregnancy, since low concentrations of 25 -hydroxy vitamin D (25-OHD) are found at this time. ${ }^{2}{ }^{4-6}$ Possible neonatal consequences of this deficiency include hypocalcaemia, ${ }^{7}$ craniotabes, ${ }^{6}$ and frank rickets. ${ }^{8}$ Since the risks to the fetus of subclinical maternal vitamin $\mathrm{D}$ deficiency are not clearly defined and since birth size of Indian Asians in Britain is less than that of north Europeans and Negroes, ${ }^{910}$ we have undertaken a trial, using calciferol (ergocalciferol) supplements, to investigate the effects of the vitamin on maternal and infant calcium homoeostasis and fetal growth. 


\section{Patients and methods}

Pregnant women-The patients were Asian women originating chiefly from the Indian subcontinent. Most were Indian, but others were from Pakistan, Bangladesh, Sri Lanka, Mauritius, and east Africa. All were first-generation immigrants. Recruitment to the trial occurred at antenatal booking after informed consent had been obtained, if necessary through an interpreter. Blood was taken at 28-32 weeks' gestation for biochemical analysis, and each patient was randomly allocated to the treatment (calciferol $1000 \mathrm{IU} /$ day) or control (placebo) group, the preparation to be taken until term. The trial was double blind. At the end of the trial, and after necessary exclusions (see below), there were 67 women in the control group and 59 in the treatment group. There were no significant differences between the groups in maternal age, parity, height (table I), vegetarian: non-vegetarian ratio (control group $1: 2 \cdot 7$, treatment group $1: 3 \cdot 2$ ), or the distribution of the various countries of origin (both groups consisting of about $70 \%$ Indians and $17 \%$ Pakistanis). Significances of these differences were determined by the $\chi^{2}$ test. Maternal weight gain during the last trimester was recorded and dietary sources of vitamin $\mathrm{D}$ identified by questionnaire as far as possible. Cord blood and postpartum maternal blood were obtained at term for biochemical analysis, and blood was taken from the infant on day 3 and day 6 for estimation of plasma calcium concentration.

TABLE I-Maternal age, height, and parity in two groups of pregnant Asian women. Results given as means $\pm S D$ or as percentages (in parentheses)

\begin{tabular}{|c|c|c|}
\hline & $\begin{array}{c}\text { Control group } \\
(n=67)\end{array}$ & $\begin{array}{l}\text { Treatment group } \\
\qquad(\mathrm{n}=59)\end{array}$ \\
\hline $\begin{array}{l}\text { Age }(y r) \\
\text { Height }(\mathrm{cm})\end{array}$ & $\begin{aligned} 23 \cdot 7 & \pm 3 \cdot 1 \\
156 \cdot 4 & \pm 6 \cdot 1\end{aligned}$ & $\begin{array}{r}23 \cdot 9 \pm 4 \cdot 8 \\
157 \cdot 3 \pm 5 \cdot 1\end{array}$ \\
\hline $\begin{array}{l}\text { Primiparous } \\
\text { Para 1 } \\
\text { Para 2+ }\end{array}$ & $\begin{array}{l}(58) \\
(24) \\
(18)\end{array}$ & $\begin{array}{l}(53) \\
(27) \\
(20)\end{array}$ \\
\hline
\end{tabular}

Neonatal assessment-All infants were clinically examined by one of us (OGB) and the following measurements made within the first 48 hours: weight, crown-heel length, ${ }^{11}$ crown-rump length, ${ }^{11}$ rumpheel length, ${ }^{11}$ occipitofrontal head circumference, mid-upper arm circumference, maximum calf circumference, forearm length, ${ }^{10}$ lower leg length, ${ }^{10}$ triceps and subscapular skinfold thickness, ${ }^{12}$ and fontanelle area. ${ }^{13}$

Biochemical measurements-Serum 25-OHD concentration was measured by a competitive protein-binding assay after chromatographic purification of lipid extracts of serum. ${ }^{14}$ Plasma calcium, inorganic phosphate, bilirubin, and albumin concentrations and total alkaline phosphatase activity were measured by standard autoanalyser methods (Technicon AAII). Alanine transaminase and $\gamma$-glutamyl transferase activities were determined using commercial kits (Boehringer Mannheim GMBH) on an LKB8600 reaction-rate analyser. The contribution of the placental isoenzyme to the total alkaline phosphatase activity was estimated by noting the residual enzyme activity after heating the plasma at $65^{\circ} \mathrm{C}$ for 30 minutes. Liver and bone isoenzyme activities were estimated electrophoretically. ${ }^{15}$ Plasma calcium concentrations in maternal and cord blood samples were adjusted for albumin concentration. ${ }^{16}$ Vitamin D binding globulin concentration was measured with M-Partigen immunodiffusion plates (Hoechst Pharmaceuticals).

Patient compliance-The dose of calciferol (1000 IU/day) was selected as that likely to be adequate without being toxic. There were no differences in concurrent drug treatment of patients in the treatment and control groups. When the code was broken and the treatment group identified, it became apparent that four out of the 63 women in the treatment group had not taken their calciferol, since their plasma concentrations were lower than those of the others by a factor of 10 or more. They were, however, included in subsequent analyses. Although two women in the control group had probably taken extra vitamin $\mathrm{D}$ they were also included.

Exclusions from the trial-Preterm deliveries, congenital malformations, and maternal illnesses likely to affect fetal growth (such as diabetes) were reasons for exclusion.

Allowance for seasonal effects-To avoid distortion of the results owing to seasonal variation in sunlight hours the trial spanned autumn and winter 1977, the whole of 1978, and spring and summer 1979.

Ethical approval was obtained from the hospital ethical committee.

\section{Results}

\section{MATERNAL WEIGHT GAIN}

Mean daily weight gain was $46.4 \pm \operatorname{SEM} 3.6 \mathrm{~g}$ in mothers in the control group and $63.3 \pm 2.6 \mathrm{~g}$ in mothers in the treatment group. This difference was highly significant $(t=3 \cdot 7, \mathrm{p}<0 \cdot 001)$.

\section{MATERNAL AND CORD BLOOD BIOCHEMICAL RESULTS}

Table II shows the main biochemical results. Plasma concentrations of 25-OHD at allocation (28-32 weeks) were similar in the treatment and control groups $(20.2$ and $20.0 \mathrm{nmol} / 1,8.1$ and $8.0 \mathrm{ng} / \mathrm{ml}$, respectively) and ranged from undetectable values to $92 \mathrm{nmol} / \mathrm{l}(36 \cdot 9$ $\mathrm{ng} / \mathrm{ml}$ ). Significantly more vegetarians had undetectable $25-\mathrm{OHD}$ concentrations than non-vegetarians $\left(71 \% v 12 \%, \chi^{2}=11.2, \mathrm{p}<0.01\right)$. In the control group there was a decline in plasma 25-OHD concentrations between 28 weeks and term, although this was only just significant (paired $t$ test: $t=1.91,0.1>\mathrm{p}>0.05)$. Maternal and cord blood 25-OHD concentrations correlated well $(r=0.93, p<0.001)$ and the maternal concentration was significantly greater than that of cord blood both in the control group $(\mathrm{p}<0.02$, paired $t$ test) and in the treatment group $(\mathrm{p}<0.01$, paired $t$ test). Because of the wellknown seasonal variation ${ }^{17}$ we pooled results from those samples taken in the summer months (May-October) and those taken in the winter months (November-April) separately. The differences were not significant, although the mean plasma 25-OHD concentrations were higher in the summer months in mothers both at 28 weeks and at term and also in the cord blood.

The plasma calcium concentration (adjusted for albumin) rose significantly in both groups during the third trimester $(p<0.001)$ but to a greater extent in the treatment group $(p<0.001)$.

The alkaline phosphatase activity in both maternal and cord blood was higher in the control group than in the treatment group. In all 89 cord blood samples tested the bone isoenzyme was clearly detectable, but only six of these showed any traces of liver isoenzyme activity. Table II shows that the mean placental contribution was under $5 \mathrm{IU} / 1$. Maternal samples showed liver, bone, and placental isoenzyme bands. In the absence of an increase in the plasma activities of the other liver enzymes (alanine transaminase and $\gamma$-glutamyl transferase), however, any rise in heat-labile alkaline phosphatase activity was probably due to the bone isoenzyme. Hence the higher alkaline phosphatase activity in maternal and cord plasma in the control

TABLE II-Maternal and cord plasma biochemical results in two groups of pregnant Asian women and their infants. Results given as means \pm SEM

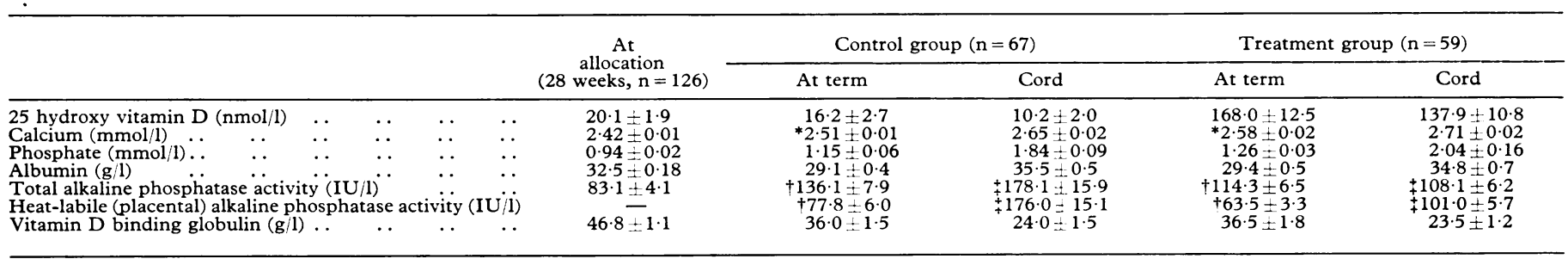

Difference between means (control group $v$ treatment group) significant at: ${ }^{*} \mathrm{p}<0.01,+\mathrm{p}<0.05,+\mathrm{p}<0.001$.

Conversion: SI to maditiongl Conversion: SI to traditional units-Plasma
$100 \mathrm{ml}$. Plasma albumin $: 1 \mathrm{~g} / \mathrm{2} \approx \mathrm{g} \cdot \mathrm{g} / 100 \mathrm{ml}$. 
TABLE III-Mean $( \pm S E M)$ anthropometric values in infants of two groups of Asian mothers

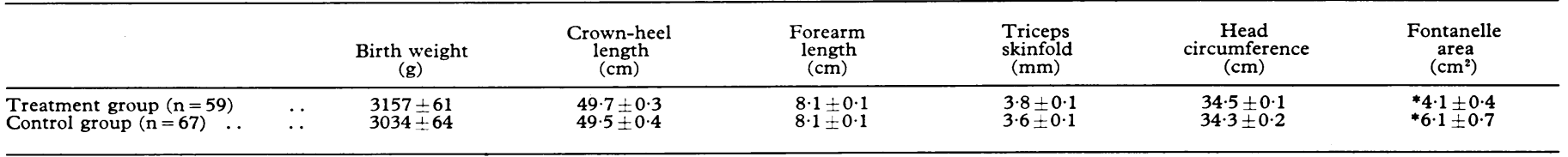

*Difference between means significant; $t=2 \cdot 4, \mathrm{p}<0.05$.

group was caused by increased bone isoenzyme activity. In both maternal and cord samples the bone alkaline phosphatase activity was clearly related to plasma 25-OHD concentration. At 25-OHD concentrations of under $25 \mathrm{nmol} / 1(10 \mathrm{ng} / \mathrm{ml}), 20 \%$ of maternal samples and $38 \%$ of cord samples had heat-labile alkaline phosphatase activities over $105 \mathrm{IU} / 1$ and $165 \mathrm{IU} / 1$ respectively. These values were estimated from our data to be the upper limits of the heat-labile enzyme activity in vitamin $D$ replete subjects. Conversely, only $2 \%$ of maternal and $4 \%$ of cord samples with $25-\mathrm{OHD}$ concentrations over $25 \mathrm{nmol} / 1(10 \mathrm{ng} / \mathrm{ml})$ had enzyme activities greater than these limits.

No significant differences in albumin or inorganic phosphate concentrations were found between the two groups. There was no correlation between maternal and cord blood calcium concentration or heat-labile alkaline phosphatase activity. When the control and treatment groups were considered separately there was no correlation between concentrations of 25-OHD and calcium except for a weak one in cord blood in the treatment group $(r=0.31, p<0.05)$.

\section{RESULTS IN INFANTS}

Gestation-Mean gestation was $39 \cdot 1 \pm 0 \cdot 2$ SEM weeks in the treatment group at birth and $39 \cdot 3 \pm 0 \cdot 2$ weeks in the control group.

Sex distribution-The female: male ratio was $1: 1 \cdot 3$ in both groups.

Anthropometry-Table III shows the results of selected anthropometric measurements. The only significant difference in any of the measurements was in fontanelle area, which was greater in the control group $(t=2 \cdot 4, \mathrm{p}<0.05)$. These infants, however, showed a trend to smaller size with lower means in eight of the 11 other measurements. There was no difference in linear proportions (crownrump: rump-heel ratio) between the two groups. The incidence of infants that were small for gestational age (less than the 10th weight centile, Gairdner standards ${ }^{18}$ in the control group was $28.6 \%$ (19 out of 67 ) and in the treatment group $15.3 \%$ (9 out of 59 ). This difference was not significant. $\left(\chi^{2}=3 \cdot 1,0 \cdot 10>\mathrm{p}>0.05\right)$.

Calcium concentrations-Table IV shows the postnatal infant calcium concentrations. Plasma calcium concentrations were significantly higher on days 3 and 6 in the treatment group than in the control group. Plasma calcium concentrations under $2 \mathrm{mmol} / \mathrm{l}$ $(8 \mathrm{mg} / 100 \mathrm{ml})$ were found significantly more often in infants in the control group $\left(24.6^{\circ}\right)$ than in those in the treatment group $(6.3 \%$, $\left.\chi^{2}=4.9, \mathrm{p}<0.01\right)$

TABLE IV-Mean ( $\pm S E M)$ postnatal plasma calcium concentrations in infants of two groups of Asian mothers

\begin{tabular}{|c|c|c|c|c|c|}
\hline & & & \multicolumn{3}{|c|}{ Plasma calcium (mmol/l) } \\
\hline & & & & Day 3 & Day 6 \\
\hline $\begin{array}{l}\text { Control group } \\
\text { Treatment group } \\
\text { Bottle fed } \quad \ldots \\
\text { Breast fed } \quad \text {.. }\end{array}$ & $\begin{array}{l}\ldots \\
\cdots \\
\cdots\end{array}$ & $\begin{array}{l}\ldots \\
\cdots \\
\cdots\end{array}$ & $\begin{array}{l}\ldots \\
\cdots \\
\cdots\end{array}$ & $\begin{array}{l}* 2.18 \pm 0.04 \\
* 2.30 \pm 0.04 \\
\pm 2.11 \pm 0.05 \\
\pm 2.27 \pm 0.03\end{array}$ & $\begin{array}{l}+2.29 \pm 0.02 \\
+2.49 \pm 0.04 \\
\$ 2.27 \pm 0.06 \\
\$ 2.42 \pm 0.03\end{array}$ \\
\hline
\end{tabular}

Difference between means significant at: $* \mathrm{p}<0.05,+\mathrm{p}<0.001,+\mathrm{p}<0.01$, s $<0.05$ Conversion: SI to traditional units-Plasma calcium: $1 \mathrm{mmol} / 1 \approx 4 \mathrm{mg} / 100 \mathrm{ml}$.

Method of feeding - Twenty-two per cent of mothers in the treatment group and $27 \%$ in the control group fed their infants by bottle. This resulted in lower plasma calcium concentrations in the first week than in breast-fed infants (table IV) as noted before. ${ }^{19}$ Breast-feeding did not confer full protection against the effects of fetal vitamin D deficiency, and plasma calcium concentration remained significantly lower on day 6 in the breast-fed infants in the control group than in the breast-fed infants in the treatment group $(t=2 \cdot 3, \mathrm{p}<0.05)$. Among breast-fed infants, plasma calcium concentrations under
$2 \mathrm{mmol} / 1(8 \mathrm{mg} / 100 \mathrm{ml})$ were found in $15 \%$ of those in the control group and in $3.6 \%$ of those in the treatment group.

Clinical-There were five infants in the control group with symptomatic hypocalcaemia (calcium concentration under $1.8 \mathrm{mmol} / 1$ $(7.2 \mathrm{mg} / 100 \mathrm{ml})$ with hyperirritability) and none in the treatment group. This difference was significant $\left(\chi^{2}=4 \cdot 6, p<0.01\right)$. One infant in the treatment group was hyperirritable but his calcium concentration was normal $(2.4 \mathrm{mmol} / 1,9.5 \mathrm{mg} / 100 \mathrm{ml})$, and his symptoms were attributed to a difficult birth. No infant in either group had convulsions. Six infants in the control group and two in the treatment group had craniotabes. This difference was not significant. All infants with symptomatic hypocalcaemia and craniotabes underwent radiography of the wrist, but none showed evidence of rickets.

\section{Discussion}

This is the first controlled trial of vitamin $\mathrm{D}$ supplements in Asian women during pregnancy. Our findings confirm reports of the high incidence of vitamin $\mathrm{D}$ deficiency (as measured by plasma 25-OHD concentration) in this group and demonstrate the important benefits of vitamin D supplements to these women and their infants.

Although our subjects came from a relatively affluent Asian community in the south of England, our investigations showed a high incidence of vitamin $\mathrm{D}$ deficiency during the last trimester, and the mean plasma concentration of 25-OHD in untreated subjects (about $20 \mathrm{nmol} / 1,8 \mathrm{ng} / \mathrm{ml}$ ) was much lower than those of a healthy, non-pregnant European population (25-150 nmol/1, 10-60.1 ng/ml, in summer and $20-100 \mathrm{nmol} / \mathrm{l}$, $8-40 \cdot 1 \mathrm{ng} / \mathrm{ml}$, in winter). Sustained plasma 25-OHD concentrations below $10 \mathrm{nmol} / 1(4 \mathrm{ng} / \mathrm{ml})$ are associated with osteomalacia, and initial biochemical assessment at 28-32 weeks' gestation showed $37 \%$ of pregnant Asians to have plasma 25-OHD concentrations below this value. By term, in the control group, plasma concentrations in $53 \%$ of mothers and in $64 \%$ of cord blood samples fell below this value. This fall was accompanied by significant increases in plasma bone alkaline phosphatase activity in the untreated mothers and their infants, indicating subclinical bone disease.

It is uncertain whether an inadequate diet or lack of exposure to sunlight makes a greater contribution to vitamin $\mathrm{D}$ deficiency in British Asians. ${ }^{20} 21$ In light-skinned races exposure to sunlight is important in ensuring adequate stores of vitamin $D$ since the plasma 25-OHD concentration is higher during summer months. ${ }^{22}$ Our findings, however, showed no such seasonal variation in $25-\mathrm{OHD}$ concentration. This may reflect both the different cultural attitudes that result in reduced exposure to sunlight during pregnancy in Asian women and the reduced synthesis of vitamin $D$ in pigmented skin exposed to weaker sunlight. Under these circumstances dietary inadequacy becomes important. Our findings of a higher incidence of severe deficiency in vegetarians support the view that dietary intake may be the major factor determining vitamin $\mathrm{D}$ stores in Asian women in the United Kingdom. We found no evidence to suggest that changes in concentrations of vitamin $\mathrm{D}$ binding protein had any importance in determining vitamin $\mathrm{D}$ deficiency in the controls (table II), though loss of the binding protein in the urine may be associated with rickets in nephrotic patients. ${ }^{23}$

Whatever the explanation for vitamin D deficiency in Asian women during pregnancy, our findings showed that supplementation with calciferol (1000 IU/day) was sufficient to 
produce a striking improvement in measured maternal and neonatal biochemical indices. We do not know whether vitamin D supplements improved subjective maternal wellbeing during pregnancy, since we deliberately avoided asking about symptoms because of the notorious vagueness of these in early osteomalacia and because of the difficulty in interpreting symptoms in non-English speaking women.

Interestingly, however, mothers receiving supplements gained more weight in the last trimester than the controls. The average weight gain in the treatment group (63 g/day) was near the quoted average weight gain for European women in their last trimester $(71 \mathrm{~g} /$ day $) .{ }^{24}$ The suboptimal average weight gain of the control group ( $46 \mathrm{~g} /$ day) may have been due to reduced appetite and food intake resulting from the ill-defined malaise that accompanies osteomalacia. There is additional evidence that some pregnant Asian women are undernourished, ${ }^{25}$ which has obvious implications for the growth and welfare of the fetus. Since plasma albumin concentrations did not differ between the two groups, the controls probably did not have dietary protein deficiency. We have insufficient data on energy intake, however, which is probably a more important determinant of fetal growth.

Our findings also showed a significant increase in cord blood 25-OHD concentration and in postnatal plasma calcium concentrations in infants of mothers receiving calciferol. The low cord plasma 25-OHD concentrations in infants in the control group were associated with disordered calcium homoeostasis, since low calcium concentrations were often seen in these infants but were rarely seen in the infants in the treatment group. Furthermore, none of the infants in the treatment group developed symptomatic hypocalcaemia, whereas five infants from the control group did. Breast-feeding, with its lower phosphate intake, improved the infants' calcium concentrations but did not counteract the effects of vitamin D deficiency.

Although we could not show that vitamin D supplementation had a significant effect on infant birth weight, the number of infants who were small for gestational age in the control group was almost twice that in the treatment group. Although this difference fell just short of significance at the 5\% level, we consider that vitamin D deficiency could well contribute towards the high incidence of low birth-weight infants among British Asians. No information has been available on the role of vitamin $\mathrm{D}$ in fetal bone growth. The close correlation between maternal and fetal vitamin D concentrations shown in this and other studies ${ }^{5}{ }^{6}$ suggests that the vitamin is neither synthesised nor selectively retained by the fetus. The lack of effect of supplementation on neonatal linear measurements implies that vitamin $\mathrm{D}$ is not a limiting factor on bone growth in utero. Nevertheless, there was presumably some interference with normal skull ossification since the fontanelles were larger in the infants in the control group, and the higher bone alkaline phosphatase activities in cord blood suggests that untreated infants, like their mothers, had subclinical bone disease. Studies of the possible long-term harmful effects on dentition and postnatal bone growth are being performed.

Our results provide substantial evidence in favour of supplementing the vitamin $\mathrm{D}$ intake of pregnant Asian women in the United Kingdom for at least the last trimester. A daily supplement of 1000 IU of calciferol prevents deficiency without causing toxicity. This measure would be easy to introduce and is relatively cheap. Supplementation during pregnancy seems preferable to widespread supplementation of milk (as practised in the USA) or Asian foods such as chapati flour, since these measures might be ineffective in women at risk but lead to excessive intake in other adults.

IB thanks the pathological research fund, St George's Hospital Medical School and the South-west Thames Regional Health Authority for financial support. We are grateful to Miss Anita Sood and $\mathrm{Mr} \mathrm{D}$ Haswell for help with the 25-OHD assays and to the many nurses and paediatric house officers without whose help the study could not have been done.

\section{References}

1 Leading Article. Rickets in Asian immigrants. Br Med $\mathcal{F} 1979$;ii:1744

2 Turton CWG, Stanley P, Stamp TCB, Maxwell JD. Altered vitamin D metabolism in pregnancy. Lancet 1977; i:222-4.

${ }^{3}$ Swan CHJ, Cooke WT. Nutritional osteomalacia in immigrants in an urban community. Lancet 1971 ;ii:456-9.

4 Dent CE, Gupta MM. Plasma 25-hydroxy vitamin D levels during pregnancy in Caucasians and in vegetarian and non-vegetarian Asians. Lancet 1975 ;ii:1057-60.

5 Hillman LS, Haddad JG. Human perinatal vitamin D metabolism I: 25 -hydroxy vitamin $\mathrm{D}$ in maternal and cord blood. $\mathcal{F}$ Pediatr $1974 ; 84$ : 742-9.

${ }^{6}$ Heckmatt JZ, Peacock M, Davies AEJ, McMurray J, Isherwood DM. Plasma 25-hydroxy vitamin D in pregnant Asian women and their babies. Lancet 1979 ;ii:546-9.

7 Roberts S, Cohen M, Forfar J. Antenatal factors associated with neonatal hypocalcaemic convulsion. Lancet 1973 ;ii :809-11.

${ }^{8}$ Ford JA, Davidson DC, McIntosh WB, Fyfe WB, Dunnigan MG. Neonatal rickets in Asian immigrant populations. $B r$ Med $\mathcal{F} 1973$;iii: 211-2.

${ }^{9}$ Grundy MFB, Hood J, Newman GB. Weight standards in a community of mixed racial origin. Br $\mathcal{F}$ Obstet Gynaecol 1978;85:481-6.

10 Alvear J, Brooke OG. Fetal growth in different racial groups. Arch Dis Child 1978;53:27-32.

11 Tanner JM, Whitehouse RH, Takaishi M. Standards from birth to maturity for height, weight, height velocity, and weight velocity: British children, 1965. Arch Dis Child 1966;41:454-71, 613-35.

12 Tanner JM, Whitehouse RH. Revised standards for triceps and subscapular skinfolds in British children. Arch Dis Child 1975;50:142-5.

${ }^{13}$ Davies DP, Ansari BM, Cooke TJH. Anterior fontanelle size in the neonate. Arch Dis Child 1975;50:81-3.

14 Haddad JG, Chyu KJ. Competitive protein-binding radioassay for $25-$ hydroxy cholecalciferol. F Clin Endocrinol Metab 1971;33:992-5.

15 Cleeve HJW. Origin of an elevated plasma alkaline phosphatase activity in non-jaundiced patients. Ann Clin Biochem 1978;15:86-90.

${ }^{16}$ Payne RB, Little AJ, Williams RB, Milner JR. Interpretation of serum calcium in patients with abnormal serum proteins. Br Med $\mathcal{f} 1973$;iv: 643-6.

17 Stamp TCB, Round JM. Seasonal changes in human plasma levels of 25-hydroxy vitamin D. Nature $1974 ; 247: 563-5$.

18 Gairdner D, Pearson J. A growth chart for premature and other infants. Arch Dis Child 1971;46:783-7.

19 Watney PJM. Maternal factors in the aetiology of neonatal hypocalcaemia. Postgrad Med 7 1975;51, suppl 3:14-7.

${ }^{20}$ Polanska N, Dale RA, Wills MR. Plasma calcium levels in pregnant Asian women. Ann Clin Biochem 1976;13:339-44.

21 Gupta MM, Round JM, Stamp TCB. Spontaneous cure of vitamin D deficiency in Asians during summer in Britain. Lancet $1974 ; \mathrm{i}: 586-8$.

${ }^{22}$ Poskitt EME, Cole TJ, Lawson DEM. Diet, sunlight, and 25-hydroxy vitamin $\mathrm{D}$ in healthy children and adults. $\mathrm{Br}$ Med $\mathcal{F} 1978$; : 221-3.

${ }^{23}$ Barragry JM, France MW, Carter ND, et al. Vitamin D metabolism in nephrotic syndrome. Lancet 1977; ii:629-32.

${ }^{24}$ Metcoff J. Association of fetal growth with maternal nutrition. In: Falkner F, Tanner JM, eds. Human Growth. New York: Plenum, $1979 ; 418-9$

${ }^{25}$ Bissenden JG, Scott PH, Wharton BA. Nutrition of the Asian immigrant mother in relation to birth weight. Proc Nutr Soc 1979;38:103A.

(Accepted 2 Fanuary 1980)

ONE HUNDRED YEARS AGO A very singular and interesting case of fracture of the third cervical vertebra is reported by $\mathrm{Dr} \mathrm{H} \mathrm{F}$ Eberman of Lancaster, Pennsylvania, in the American Fournal of Medical Sciences. The patient, William Barracks, aged about 70, was making his home in a stable adjoining a hotel, and was in the habit of sleeping in the hayloft. One morning, on arising and while descending the steps, he slipped and fell, striking his occiput violently on the ground; his head was thus forcibly thrown forward on his chest, and he was rendered insensible for a considerable time. After recovering from the shock, he arose, and placing both hands to his neck, walked to the bar-room of the hotel (which is half a square from the place of accident), where he remarked that he thought his neck was hurt, and at the same time called for a glass of whiskey, which he immediately drank. He then returned to the stable, lay down on the hay, and expired in about half an hour. On the following day, a post mortern examination was made, with the following result. The third cervical vertebra was found to be fractured transversely through the body; the arch on the right side was broken entirely through; the articulating surfaces on both sides were fractured through the middle; the transverse process on the right side of the atlas was broken off; and the interspinous and posterior vertebral ligaments were ruptured; but the spinal cord remained intact. (British Medical fournal, 1880.) 